\title{
Corporate Governance Failure And Its Impact On National Australia Bank’s Performance
}

Dianne Thomson, (Email: dianne.thomson@deakin.edu.au), Deakin University, Australia Ameeta Jain, (Email: ameeta.jain@deakin.edu.au), Deakin University, Australia

\begin{abstract}
The National Australia Bank (NAB) is the largest financial services institution listed on the Australian stock exchange and is within the 30 most profitable financial services organisation in the world. In January 2004, the bank disclosed to the public that it had identified losses relating to unauthorised trading in foreign currency options amounting to AUD360 million. This foreign exchange debacle was classified as operational risk, the risk of loss resulting from inadequate or failed processes, people, or systems and reiterated the importance of corporate governance for banks. Concurrent issues of National Australia Bank's AUD4.1 billion loss on US HomeSide loans in 2001, the degree of strength of their risk management practices and lack of auditor independence, were raised by the US Securities and Exchange Commission in 2004, reinforcing the view that corporate governance had not been given the priority it deserved over a number of years. This paper will assess and critically analyse the impact of corporate governance failure by management and Board of Directors on NAB's performance over the years 2001-2005.
\end{abstract}

\section{INTRODUCTION}

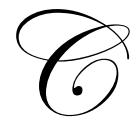

ollapse of large companies in Australia over the last decade has led to increasing public and government concern over the lack of good management practice and public accountability. Good corporate governance structures encourage creation of value, provide accountability and control systems commensurate with the risks involved (ASX, 2003) with the Board of Directors being responsible for the corporate governance of their firm. They can be best described as the internal auditors that oversee a complex set of relationships among a core group consisting of shareholders, board members, regulators and managers. The firm's internal governance should create a clear and effective structure of accountability with management being held accountable for their company's performance. Their chief concern should be how to best foster the competitive performance required to achieve the corporation's primary objective of shareholder wealth maximization. Corporate governance is not just about wealth creation it is also about risk management. The National Australia Bank's (NAB) forex scandal highlighted an operating environment characterised by lax and unquestioning oversight by line management, poor adherence to risk management systems and controls and weaknesses in internal governance procedures (APRA 2004).

The National Australia Bank is the largest financial services institution listed on the Australian stock exchange and is within the 30 most profitable financial services organisation in the world (NAB Annual Financial Report, 2004). In January 2004, the bank disclosed to the public that it had identified losses relating to unauthorised trading in foreign currency options amounting to AUD360 million. This foreign exchange debacle was classified as operational risk, the risk of loss resulting from inadequate or failed processes, people, or systems and reiterated the importance of corporate governance for banks. The Australian Prudential Regulatory Authority (APRA), the Treasury, the Certified Practicing Accountant (CPA) society of Australia and other monitoring bodies extensively reviewed this financial disaster. The incident accelerated the release of CLERP 9 (Corporate Law Economic Reform Program) of the Australian government, which had been fortuitously in the pipeline since 2002. It is of some interest that this follows close on the heels of the ENRON collapse in the USA and the Sarbanes-Oxley Act of 2002. This incident has implications for corporate governance not only for the NAB but also for other banks in Australia and internationally. 
The poor corporate governance and financial woes facing NAB commenced with the HomeSide loan crisis, a write-off of AUD4.1 billion of shareholders money in 2001, has continued with issues of auditor independence and rogue foreign exchange traders who exploited loopholes in risk management policy, has ensured that " $\ldots$ the NAB affair will be a classic study in crisis management for decades to come..." (Maiden, 2004).

The aim of this paper is to contribute to our understanding of why corporate governance failure occurred in the largest and one of the most profitable Australian banks. The impact of corporate governance failure on NAB's performance is investigated by utilising the DuPont model, whereby accounting-based measures of profitability and cost efficiency are used as proxies for performance. The paper is structured as follows: firstly, the paper will outline the development in the literature of the history of international corporate governance and its emergence in Australia in the 1980s. Secondly, the theoretical and empirical literature of corporate governance and performance are reviewed. Following sections investigate and analyse the effects of NAB corporate governance failure on shareholder returns, regulatory burden and company performance by examining the financial statements and key profitability and cost performance indicators. In the final sections the paper will conclude by examining regulatory and compliance issues with some closing remarks identifying areas for future research.

\section{REVIEW OF CORPORATE GOVERNANCE HISTORY}

Gay and Sinnet (2000) define corporate governance as the system by which companies are governed and controlled. Whereas, Woodward, Bird and Sievers $(2001,498)$ define corporate governance as a "catch all phrase used to refer to management issues, incorporations and the mechanisms by which corporate management can be supervised and made accountable to its members, employees, creditors and the community".

\section{International Perspective}

The history of corporate governance is virtually as old as that of capitalism itself with the first recorded dispute in 1622 in the Netherlands, and whilst Adam Smith understood the issues of corporate governance in 1776, he did not use the phrase corporate governance (Morck and Steier, 2004) The first recognised academic work on the issue of corporate governance was Berle and Means (1932), followed by Coase (1937) as they recognised ownership/performance issues arising from the growing separation of power between executive management of major public companies and their increasingly remote and diverse shareholders. In more recent times the term "Corporate Governance" first surfaced in the 1970s in the USA to describe the role, functions and responsibilities of the board and management but did not appear in print until 1983 (Earl, 1983).

The link between corporate governance and principal-agent problems is further highlighted by Farrar (1999) who traces the development of corporate governance with the appearance of managerial capitalism and the need to raise capital from the public. Farrar's view is that in the absence of a countervailing power, management have a tendency to pursue their own self-interest at the expense of the corporation. There is a need then to monitor management to prevent shirking and other opportunistic behaviour. The corporate governance issues were controlled by both fiduciary restraints developed in the common law and supplemented by legislation so that modern directors' duties are an amalgam of common law, equity and statute. The market for corporate control rewards good performance but judges under-performance with either falling share price as investors leave the stock or takeover bids occur by more aggressive managers.

The corporate management excesses that occurred from 1960 until the late 1980s led to the beginnings of corporate laws reform. Simply out of self-protection, management of leading companies through their interest groups and in cooperation with institutional investors began to give serious attention to the development of self-regulation of corporate governance. Whilst the spectacular corporate collapses in the USA in 2001 and 2002 put the spot light on corporate governance, and particularly the conduct of the directors themselves, corporate governance was high on the UK agenda before they occurred. Over the decade of the 1990's, the UK had been recognised the world leader on best practice of corporate governance leading to a number of reports and codes or guidelines on corporate governance (see Table 1). 
Table 1: Development Of International Corporate Governance

\begin{tabular}{|c|c|c|c|}
\hline Author & Year & Report & Comments Or Key Suggestions \\
\hline $\begin{array}{l}\text { British Accounting } \\
\text { Standards and Steering } \\
\text { Committee (UK) }\end{array}$ & 1975 & "The Corporate Report" & $\begin{array}{l}\text { All economic entities to report publicly and accept } \\
\text { accountability for the impact of director's decisions }\end{array}$ \\
\hline Rhys Williams (UK) & 1977 & $\begin{array}{l}\text { "The Conduct of } \\
\text { Company Directors" }\end{array}$ & $\begin{array}{l}\text { Green Paper presented to British Parliament - did not see } \\
\text { the light of day }\end{array}$ \\
\hline $\begin{array}{l}\text { London Stock Exchange } \\
\& \text { Financial Reporting } \\
\text { Council } \\
\text { The Cadbury Committee } \\
\text { (UK) }\end{array}$ & 1992 & $\begin{array}{l}\text { "The Financial Aspects } \\
\text { of Corporate } \\
\text { Governance" } \\
\text { The Cadbury Report }\end{array}$ & $\begin{array}{l}\text { Boards should have checks and balances to ensure that no } \\
\text { single individual could have "unfettered powers of } \\
\text { decision", should have at least } 3 \text { non-executive members of } \\
\text { which } 2 \text { should be fully independent, should have an audit } \\
\text { committee, and should explain its corporate governance } \\
\text { procedures. }\end{array}$ \\
\hline $\begin{array}{l}\text { Rutterman Committee } \\
\text { (UK) }\end{array}$ & 1994 & Rutterman Report & Internal control and financial reporting \\
\hline $\begin{array}{l}\text { Greenbury Committee } \\
\text { (UK) }\end{array}$ & 1995 & $\begin{array}{l}\text { "Directors' } \\
\text { Remuneration: the } \\
\text { report of a study group" } \\
\text { The Greenbury Report }\end{array}$ & $\begin{array}{l}\text { Transparency or lack thereof in directors remuneration } \\
\text { disclosure in the UK }\end{array}$ \\
\hline Hampel Committee (UK) & 1995 & $\begin{array}{l}\text { "Committee on } \\
\text { Corporate Governance" } \\
\text { report" }\end{array}$ & $\begin{array}{l}\text { Reviewed the decisions of the Cadbury committee and } \\
\text { included more detailed and more rigid prescriptions for } \\
\text { companies, boards of directors and audit processes. }\end{array}$ \\
\hline $\begin{array}{l}\text { California Public } \\
\text { Employees Retirement } \\
\text { System (CalPERS) }\end{array}$ & $\begin{array}{l}1997 \text { and } \\
\text { revised } \\
\text { in } 1999\end{array}$ & $\begin{array}{l}\text { Global Corporate } \\
\text { Governance }\end{array}$ & Good governance needs to be accountable and transparent. \\
\hline $\begin{array}{l}\text { Business Roundtable (An } \\
\text { association of the chief } \\
\text { executives of the top } 250 \\
\text { companies in the USA) }\end{array}$ & 1997 & $\begin{array}{l}\text { Statement on Corporate } \\
\text { governance }\end{array}$ & $\begin{array}{l}\text { Revised roles of boards committees, the composition of the } \\
\text { board and the evaluation of governance process. }\end{array}$ \\
\hline $\begin{array}{l}\text { The Turnbull Committee } \\
\text { (UK) }\end{array}$ & 1998 & Turnbull Report & $\begin{array}{l}\text { Implementing a risk-based approach to systems of internal } \\
\text { control and meaningful disclosure }\end{array}$ \\
\hline $\begin{array}{l}\text { The Asia Pacific } \\
\text { Economic Cooperation } \\
\text { symposium (APEC) }\end{array}$ & 1998 & $\begin{array}{l}\text { APEC finance ministers } \\
\text { report }\end{array}$ & $\begin{array}{l}\text { Improve corporate governance in the region to assist in } \\
\text { restoring financial stability and growth the ravaged South } \\
\text { East Asian Tiger Economies. }\end{array}$ \\
\hline $\begin{array}{l}\text { Organization for } \\
\text { Economic Co-operation } \\
\text { and Development }\end{array}$ & 1998 & $\begin{array}{l}\text { Corporate Governance } \\
\text { Report: Improving } \\
\text { Competitiveness and } \\
\text { Access to Capital in } \\
\text { Global Markets }\end{array}$ & $\begin{array}{l}\text { Protection of shareholders rights, equitable treatment of } \\
\text { shareholders, the role of stakeholders in corporate } \\
\text { governance, disclosure and transparency and the } \\
\text { responsibilities of the board. Integrity of internal control } \\
\text { structures and accountability, transparency and disclosure } \\
\text { of board members and executive staff. }\end{array}$ \\
\hline $\begin{array}{l}\text { The Hampel Report } \\
\text { (consolidating the } \\
\text { Cadbury, Greenbury and } \\
\text { Hampel Reports) UK }\end{array}$ & 1998 & The Combined Code & $\begin{array}{l}\text { Requires companies to provide disclosure statement on } \\
\text { their adherence to the principles of good governance }\end{array}$ \\
\hline $\begin{array}{l}\text { US Federal Government, } \\
\text { NYSE }\end{array}$ & 2002 & Sarbanes-Oxley Act & $\begin{array}{l}\text { Required that the CFO and the CEO certify that the verity } \\
\text { of the financial statements and be personally responsible } \\
\text { for them }\end{array}$ \\
\hline $\begin{array}{l}\text { Coordinating Group on } \\
\text { Auditing and Accounting } \\
\text { Issues in the UK (CGAA) }\end{array}$ & 2003 & Final CGAA Report & $\begin{array}{l}\text { Recommended the formation of an independent group to } \\
\text { develop the existing guidance on audit committees } \\
\text { contained in the Combined Code and to clarify the roles of } \\
\text { audit committees with the backing of the British Financial } \\
\text { Reporting Council }\end{array}$ \\
\hline Derek Higgs (UK) & 2003 & Higgs Report & $\begin{array}{l}\text { Independent review of the role and effectiveness of non- } \\
\text { executive directors on a board of directors }\end{array}$ \\
\hline $\begin{array}{l}\text { European Corporate } \\
\text { Governance Forum }\end{array}$ & 2004 & $\begin{array}{l}\text { "High level Group of } \\
\text { Experts" Report }\end{array}$ & $\begin{array}{l}\text { To enhance the convergence of national corporate } \\
\text { governance codes }\end{array}$ \\
\hline
\end{tabular}




\section{Australian Perspective}

Australia has historically followed the British common law framework and has continued this tradition with the British law for corporate governance. This provided the framework for the development of our own corporate governance laws and acts in the last two decades. Australia's corporate governance evolution has been recent with most of its development occurring in the past 4 years, stimulated by the recent worldwide corporate collapses of ENRON, WorldCom, Arthur Anderson, Pyramid, and closer to home: Ansett, HIH, and OneTel. The corporate collapses occurring in the past five years have all been a reflection of poor management and regulatory practices, and whilst NAB has not been a corporate collapse, its management has engaged in poor corporate governance that has seen billions of dollars of shareholder funds written off. Table 2 outlines the development of corporate governance in Australia.

Table 2: Development Of Australia's Corporate Governance

\begin{tabular}{|c|c|c|c|}
\hline Author & Year & Report Or Act & Comments Of Key Suggestions \\
\hline $\begin{array}{l}\text { Commonwealth } \\
\text { Government }\end{array}$ & 1989 & $\begin{array}{l}\text { Australian Securities and } \\
\text { Investments Commission Act }\end{array}$ & $\begin{array}{l}\text { Set out the role of ASIC as a watchdog of corporate } \\
\text { governance in Australia }\end{array}$ \\
\hline Henry Bosch & 1991 & $\begin{array}{l}\text { "Corporate Practices and } \\
\text { Conduct" }\end{array}$ & $\begin{array}{l}\text { Set out the functions of boards of directors, structure, } \\
\text { function, remuneration, financial reporting and auditing, } \\
\text { risk and control management }\end{array}$ \\
\hline $\begin{array}{l}\text { The Australian Institute } \\
\text { of Investment Managers } \\
\text { (AIMA) }\end{array}$ & 1995 & $\begin{array}{l}\text { "Corporate Governance: A } \\
\text { Guide for Investment } \\
\text { Managers and a Statement of } \\
\text { Recommended Corporate } \\
\text { Practice". }\end{array}$ & Published the standards of conduct \\
\hline $\begin{array}{l}\text { Commonwealth } \\
\text { Government }\end{array}$ & 1997 & $\begin{array}{l}\text { Corporate Law Economic } \\
\text { Reform Program (CLERP 1) }\end{array}$ & Australian Accounting Standards Board reinstituted \\
\hline $\begin{array}{l}\text { Commonwealth } \\
\text { Government }\end{array}$ & 1998 & $\begin{array}{l}\text { CLERP 5: Company Law } \\
\text { Review Act (1998) } \\
\text { Payments Systems and Netting } \\
\text { Act (1998) }\end{array}$ & Reforms relating to electronic commerce \\
\hline $\begin{array}{l}\text { Commonwealth } \\
\text { Government }\end{array}$ & 2001 & Corporations Act 2001 & $\begin{array}{l}\text { Mandatory Corporate Governance Compliance, covers } \\
\text { all aspects of company law }\end{array}$ \\
\hline ASX & 2002 & $\begin{array}{l}\text { Corporate Governance } \\
\text { Council }\end{array}$ & $\begin{array}{l}\text { Develop recommendations which reflect International } \\
\text { Best Practices of Corporate Governance }\end{array}$ \\
\hline $\begin{array}{l}\text { Charles Report: The Joint } \\
\text { Parliamentary Committee } \\
\text { of Public Accounts and } \\
\text { Audit }\end{array}$ & 2002 & $\begin{array}{l}\text { Review of Independent } \\
\text { Auditing by Registered } \\
\text { Company Auditors }\end{array}$ & $\begin{array}{l}\text { Made changes to the Corporations Act } 2001 \text { in that } \\
\text { auditors were to rotate, limit the ability of audit firms to } \\
\text { do non-audit work, and stricter professional and probity } \\
\text { requirements for auditors }\end{array}$ \\
\hline $\begin{array}{l}\text { The Group of } 100 \text { (CFOs } \\
\text { of the top } 100 \text { companies } \\
\text { in Australia) }\end{array}$ & 2003 & $\begin{array}{l}\text { "Guide to review of operations } \\
\text { and Financial Condition" }\end{array}$ & Code of Conduct \\
\hline ASX & 2003 & $\begin{array}{l}\text { Principles of Good Corporate } \\
\text { Governance and Best Practice } \\
\text { Recommendations }\end{array}$ & $\begin{array}{l}\text { Director independence, accountability, transparency and } \\
\text { disclosure }\end{array}$ \\
\hline ASX & 2003 & $\begin{array}{l}\text { Disclosure Listing Rule } 3.1 \\
\text { and new rule } 18.7 \mathrm{~A}\end{array}$ & $\begin{array}{l}\text { Required to provide ASX with evidence of continuous } \\
\text { disclosure }\end{array}$ \\
\hline CPA & 2003 & $\begin{array}{l}\text { Corporate Governance } \\
\text { Principles }\end{array}$ & $\begin{array}{l}\text { Reducing the number of boards on which a Board } \\
\text { member can be nominated. }\end{array}$ \\
\hline $\begin{array}{l}\text { Commonwealth } \\
\text { Government }\end{array}$ & 2004 & CLERP 9 & Accounting standards and board responsibility. \\
\hline $\begin{array}{l}\text { Commonwealth } \\
\text { Government }\end{array}$ & 2005 & $\begin{array}{l}\text { The International Financial } \\
\text { reporting Standards }\end{array}$ & Increased board accountability. \\
\hline
\end{tabular}




\section{CORPORATE GOVERNANCE AND REGULATION}

"Corporate governance crisis and reform is cyclical. Waves of corporate governance reform and increased regulation occur during periods of recession, corporate collapse and re-examination of the viability of regulatory systems. During long periods of expansion, active interest in the conformance aspects of governance diminishes, as companies and shareholders become again more concerned with the generation of wealth, rather than ensuring government mechanisms are working appropriately for wealth retention...". Clarke (2004) Market systems are volatile, competitive and dynamic. These exert a covert control over company boards, there being a significant pressure to perform.

The highly publicised nefarious activities of Australian corporate highfliers, Christopher Skase and Alan Bond, in the late 1980s, prompted the then Labour government to begin the process of implementing corporation laws in the early 1990s. The change of government in 1995 modified the focus of reform delaying the passage of the Second Corporate Law Simplification Bill until 1996. CLERP was commenced as an ongoing review and reform process in 1997 to review and reform the country's corporate and business regulation.

The Corporate Law Economic Reform Program 9 (CLERP 9) has been the most significant addition to corporate governance regulation in Australia drawing on both British and US advances in this area. It also draws on the recommendations of the Australian Federal Government's September 2003 response to the recommendations contained in the Report of the HIH Royal Commission released in April 2003. The major changes in CLERP 9 are the incorporation of the recommendation of the Ramsay Report on the independence of Australian company auditors, incorporation of the changes to NYSE Listing Rules and the Sarbanes-Oxley Act of 2002, consideration of the developments in the UK with the release of the Higgs Report on non-executive directors, the Smith report on Audit function, the proposed changes to the combined code and the ASX listing rule amendments on enhanced disclosure and corporate governance and the establishment of the ASX Corporate Governance Council and the release by this council of its principles of Good Corporate Governance and Best Practice Recommendations in March 2003.

The Australian Prudential and Regulatory Authority (APRA) have used the services of Corporate Governance International Pty Ltd since 1994 to provide it with rating and analysis of large regulated financial institutions listed on the Australian Stock Exchange. APRA also uses a "PAIRS" risk rating system to assess the strengths and weaknesses of boards. (APRA, 2002)

In May 2005, APRA released a discussion paper to introduce new governance requirements for APRA regulated institutions. The majority of APRA regulated institutions are not listed on the ASX and therefore not subject to the ASX Corporate Governance guidelines. These address the appointment of the chairperson of the board, board size and composition, board member resignations, independence of directors and external auditors, establishment of board audit and risk committees, board and senior management performance, length of service of directors, independence of external auditors and actuaries consistent with CLERP 9, internal audit and Australian operations of foreign entities.

\section{CORPORATE GOVERNANCE AND CORPORATE PERFORMANCE LITERATURE REVIEW}

There have been a number of studies that have examined the issues of corporate governance and performance exploring issues such as board size, interlocking, and director's remuneration.. A smaller body of literature investigates links between stock prices and profitability (Karathanasis and Philippus, 1998). The evidence is not clearcut but intuitively there would appear to be a positive correlation between good corporate governance practice and corporate performance. A good working relationship between the board of directors, management and other stakeholders in a given firm would result in increased efficiency, throughput and profits. Analysts and markets would view these results favourably with resultant higher stock prices. Conversely, in times of corporate governance crises, this relationship would be affected and would be reflected in falling stock prices and other measures of corporate performance. 
Hart (1995) discusses the mechanisms for controlling management, how they came into existence and whether they need to be provided by statute. He outlines the "Chicago" argument that the market economy can achieve efficient corporate governance without government intervention. Accordingly, the Chicago view argues that there is no need for statutory corporate governance rules. Rather, that they will almost certainly be counter-productive as they will limit the founder's ability to tailor corporate governance to their own individual circumstances.

Heracleous (2001) in a two dimensional study evaluated the implications of CEO/Chair duality and insider/outsider board composition and organisational performance found it not to be significant. In the same study he states that operationalisation of theoretical concepts has low face validity, and that the study is too narrow by ignoring other systemic factors, a problem seen by the author in a number of other papers as well.

Korac-Kakabadse et al (2001) argued that a direct relationship between corporate governance and performance did not necessarily follow, as their review of literature did not confirm this. Dalton and Daily (1999) in their seminal article suggested that the reliance on one dimension of board roles and attributes does not ensure high levels of corporate financial performance, especially if this is at the expense of other director roles. This implies that analysis of boards of companies and their workings needs to be multidimensional and not focus on a single variable.

Parker, Peter and Turetsky (2002) investigated the association of various corporate governance attributes and financial characteristics in the survival of distressed firms. They found that firms replacing their CEO with an outsider were twice as likely to go bankrupt. They also found that large levels of insider ownership were positively associated with a good outcome. Good corporate discipline can be a result of reaction to the marketplace or from within due to good corporate governance structures and or ownership.

Nicholson and Kiel (2004) describe the functioning of a board as multidimensional and its decision making influenced by multiple factors. They formulated a diagnostic framework to analyse where and how boards are going wrong. This model of board effectiveness has four inputs, which provide the specific operating boundaries of the board. Adapting Nadler and Tushman's (1980) key inputs to the board performance relationship, there are organisation type, the company's legislative and societal framework, the organisation's constitution and lastly, company history, which reflect the broader influences of past events. The key past events that impact current corporate governance expectations are past performance, corporate culture, values and decisions on board composition that will affect how the board functions. Within this last group, board culture, the term used to describe underlying values, beliefs and norms of the board has the most significant influence. It is implicit within the firm and governs "the way we do things around here".

An empirical study conducted by Chiang (2005) on corporate governance and transparency in the high-tech industries of Taiwan found a significant positive relationship between corporate transparency and operating performance. Outside investors can then rely on the information provided by the company to make their decisions. They found a positive association between voluntary disclosure of corporate governance information and the ability to raise equity capital. Sengupta (1998) suggested that bondholders and underwriters do consider corporate disclosure policy when determining the risk premium applicable to interest rates on debt instruments and Collett and Hrasky (2005) found that board size was positively correlated with firm value, and that a positive relationship existed between the proportion of inside directors and the market based measures of performance. Doucouliagos and Hoque (2005) find that corporate governance is an important determinant of Australian bank's stock prices. The direct effect on share prices operated through willingness to pay a premium or discount for banks that have good/poor corporate governance characteristics.

\section{BRIEF HISTORY OF NATIONAL AUSTRALIA BANK}

The company traces its history back to the establishment of The National Bank of Australasia in 1858 . National Australia Bank Limited is a public limited company incorporated on June $23^{\text {rd }}, 1893$ in Australia, which is the company's main domicile. The company operates under the requirements of the Banking Act 1959 (Commonwealth) and Corporations Act 2001. NAB is the largest financial institution (by market capitalisation and total assets) listed on the Australian Stock Exchange and is within the 30 most profitable financial service 
organizations in the world with total assets of more than AUD411 billion. NAB operates in over 10 countries and has 8.4 million banking customers and 2.3 million wealth management customers. NAB operations exist in the USA, Asia, Australia, New Zealand, and the UK and the company enjoys an AA- Standard and Poor's rating. ${ }^{1}$

\section{CORPORATE GOVERNANCE FAILURES OF NAB, 2000-2004}

This paper aims to assess the impact on NAB's performance of lack of management supervision, poor adherence to risk management systems and controls and failed internal governance procedures. It was recognised and acknowledged in the NAB 2004 Annual Report that the corporate governance failure led to the company's poor results and its reputation being adversely impacted by compliance issues, insufficient accountability and the lack of a clear cultural framework.

The concurrent issues of NAB's losses on HomeSide in 2001, the degree of strength of their risk management practices and its lack of auditor independence were raised as concerns by the US Securities and Exchange Commission (SEC) in 2004 reinforcing the view that corporate governance had not been given the priority it deserved over a number of years. The latest incident of corporate governance failure relating to the fraudulent currency traders has had significant ramifications on the company in terms of the changed and increased regulatory impost, the internal implosion of the Board, with six of the twelve directors and seven executive officers resigning during 2004 and the appointment of a new external auditor. Given the magnitude of changes to the company during the 2004 year and the significant fall in its share price as the news became more widespread and digested by the market, it would be expected that there would be a negative impact on NAB's overall profitability and corporate performance. This view is supported by Corporate Monitor who found a portfolio of 36 companies, rated questionable for corporate governance, underperformed the market by $26 \%$ since June 2001 (Skadia, Corporate Monitor $)^{2}$.

\section{HomeSide US Loans}

NAB entered the US home loan market with the acquisition of HomeSide Lending Inc in 1997 when the US mortgage industry had a large number of players. Following NAB's entry into the mortgage market a wave of consolidation reduced the industry to a handful of giants that included Washington Mutual, Wells Fargo and Chase Manhattan, all having large banking operations to feed their mortgage processing division, whilst NAB had a very small retail presence in the US (Mellish, 2001). The HomeSide blunder was a series of mistakes that lead to the devaluation of the NAB script on the New York Stock Exchange (NYSE) and at home on the Australian Stock Exchange (ASX). NAB in its own inquiry stated that the reason for this was a simple blunder by NAB executives in the calculation of fees received from servicing mortgages during the life of the loan. Initially HomeSide used an internal model to determine these fees and to calculate the gross interest rate. As a part of a computer upgrade NAB executives moved to a widely used model that used the net interest rate. The models were linked together, however the difference between the net and the gross interest rate in the two models was not recognised by NAB for a period of two years. This simple mistake cost AUD755 million, in addition, assumptions in the model proved to have been wrong, costing another AUD1.4 billion. These, along with badly bungled interest rate hedging, resulted in NAB writing-down a further AUD870 million in July 2001. HomeSide was competing with other lenders who had a large retail presence in the US whereas after the sale of its US business Michigan National, NAB lost its retail front and was further exposed to the vagaries of the Mortgage processing houses. The US market works on predominantly fixed rate home loans as opposed to variable interest loans in Australia. As soon as the bank rate falls there is a stampede for refinancing of home loans leading to significant changes in market share at each such episode. These episodes combined with NAB's failure to understand the American home loan market led to total losses which mounted to AUD4.1 billion. (Mellish, 2001)

\footnotetext{
${ }^{1}$ https://www.nabmarkets.com/aboutus/aboutus.asp accessed 27 April 2004

2 Information was supplied in PPT slides presented to a corporate forum on corporate governance (2003).
} 


\section{Foreign Currency Trader Breach}

In January 2004 it came to light that unauthorised trading by NAB foreign currency traders (three in Melbourne and one in London) resulted in projected losses of AUD360 million. The losses on currency options were caused by the traders positioning the NAB's foreign currency option portfolio in expectation that the falls in the US dollar that occurred in mid-2003 would reverse and volatility stabilise. Rather than close out their positions as the market moved against them, the traders chose to conceal their true positions, allowing those positions to deteriorate before they were finally discovered and reported to management by junior employees (APRA, 2004). Frank Cicutto, the then CEO, stated that traders at the center of the scandal had exploited weaknesses in the bank's internal procedures to hide trading losses and protect bonuses. In the Corporate and Institutional Banking Market's division there were significant gaps in back office monitoring functions, weaknesses in control procedures and an absence of appropriate financial controls. The culture within this area tended to suppress bad news rather than be open and transparent about problems. It seems that there were warning signals, both inside the Company, from other market participants and from on-site risk reviews by the regulators that were not properly acted upon (NAB 2004 Annual Report).

\section{Auditor Independence Breach}

At the same time that NAB was facing a media barrage on the foreign exchange trader losses in early 2004, it came under scrutiny to ascertain whether it failed to comply with the USA Securities and Exchange Commission (SEC) requirements of auditor independence. ${ }^{3}$ Where Australian firms are listed on the NYSE or trade American Deposit Receipts (ADRs) they come under the Sarbanes-Oxley Act (2003) which bars audit firms from providing certain non-audit services to audit clients and it also precludes staff of audit firms being seconded to clients in either employee or management roles, whereas Australian law does not preclude auditors undertaking other functions (Oldfield and Cornell (2004).

NAB had seconded staff from KPMG for extended periods over the past three years to help assess the value of distressed loans in the Credit Restructuring Unit as well as perform tax and internal audit functions. NAB's use of KPMG for non-audit work has been substantial and rising, and was more than double the audit fees in 2000 and 2001. NAB's use of KPMG for non-audit services in 2003 amounted to AUD6.56 million and AUD10.81million for audit services (Oldfield and Cornell, 2004, and NAB 2004 Annual Report).

Joint provision of audit and non-audit services poses a significant problem for auditor independence. Whilst there is little clear support for the view that the joint provision of services has compromised auditor independence, it does raise the concern as to the appearance of auditor independence (CGAA, 2003).

\section{REVIEW OF NAB'S PERFORMANCE 2001-2004}

Given the significant corporate governance issues that $\mathrm{NAB}$ experienced over the past four years, it would be expected that NAB's performance in terms of profitability and cost efficiency would have deteriorated following these events. ${ }^{4}$ This section of the paper concentrates on NAB's performance over time and utilises the corporate governance issues to explain the volatility experienced in its profitability and cost efficiency measures.

Financial performance evaluation of depository institutions is multifaceted, involving ratio analysis, common size financial statements, trend analysis and consideration of additional data not always found in published reports. Integrated models, such as the Return on Equity model, widely known as the DuPont model, disaggregates return on equity into several basic components in order to isolate the sources of a firm's profitability. Return of Equity (ROE) is decomposed as a function of a bank's cost management (as measured by its net profit margin), its revenue management (as measured by its asset utilisation), and its financial leverage (as measured by its equity multiplier). This provides a diagnostic tool, which assists observers to determine why a bank's performance has deteriorated or

\footnotetext{
${ }^{3} \mathrm{NAB}$ had received a voluntary information request by the SEC to provide information regarding auditor independence.

${ }^{4}$ It is envisaged that in a further paper NAB's performance will also be compared to its peers in the banking sector.
} 
improved in comparison to its peers or its own past record (Hogan et al, 2004, and Gardner, Mills and Cooperman, 2004). Utilising trend analysis may assist in revealing long-term patterns in profitability and cost efficiency, which allows us to evaluate the ADI against its own past performance. The following data in Table 3 comes from NAB annual reports (years 2001-2004) and KPMG Financial Institution Performance Surveys (years 2001-2004).

Return on equity (ROE), is the closest an accounting measure comes to revealing how well managers have done in maximising share-holder wealth. This ratio has been variable over the five-year period demonstrating large falls in the years 2002 and 2004 (see Table 3), reflecting the 2001 HomeSide US loans write-off of AUD4.1 billion of shareholder funds and the late 2003-early 2004 foreign currency losses respectively. The financial report from NAB Directors in 2004 indicated that a number of significant items caused net profit attributable to members of the Company to decrease by $19.7 \%$ compared to its 2003 results. These significant items amounting to AUD800 million, included the AUD360 million foreign currency options trading losses, a write-down of impaired application software of AUD307 million and a charge to provide for doubtful debts of AUD204 million (NAB Annual Report, 2004). More damning for NAB's 2004 performance data is that during that year all the majors, except for NAB, achieved a positive profit earnings outcome. The average return on equity for the sector ${ }^{5}$ increased from $17.9 \%$ to $18.3 \%$ during 2004 , which KPMG considers is still slightly below the industry benchmark of $20 \%$, hence putting further pressure on NAB's poor performance with ROEs of $11.5 \%$ in 2004 and some improvement to $14 \%$ in the first half of 2005 (KPMG Financial Institutions Performance Survey, 2004, 2005).

Table 3: Selected Indicators Of Profitability And Efficiency For NAB 2001-2005 ${ }^{6}$

\begin{tabular}{|c|c|c|c|c|c|}
\hline Measurement Indicator In (\%) & 2001 & 2002 & 2003 & 2004 & $\begin{array}{c}2005 \\
\text { (first half) }\end{array}$ \\
\hline Interest Margin * & 2.71 & 2.67 & 2.53 & 2.35 & 2.19 \\
\hline Net (Profit) Margin & 25.91 & 21.87 & 47.75 & 17.63 & na \\
\hline Asset Utilisation & 5.15 & 4.28 & 4.06 & 4.62 & na \\
\hline Return on Assets* & 0.81 & 0.90 & 1.02 & 0.79 & 0.67 \\
\hline Leverage (equity) Multiplier times [x] & $14.61 \mathrm{x}$ & $15.41 \mathrm{x}$ & $14.32 \mathrm{x}$ & $14.05 \mathrm{x}$ & na \\
\hline Return on Equity & 19.51 & 14.45 & 27.78 & 11.46 & 14.0 \\
\hline Operating Expenses/ Average Total Assets* & 0.90 & 1.60 & 1.64 & 1.68 & 0.90 \\
\hline Cost to Income Ratio* & 48.5 & 47.7 & 48.4 & 50.8 & 57.4 \\
\hline Capital Adequacy Ratio* & 10.2 & 10.2 & 9.6 & 9.3 & 11.7 \\
\hline Share Price $(\$)$ & $\begin{array}{l}35.13 \\
23.80\end{array}$ & $\begin{array}{l}36.78 \\
30.87\end{array}$ & $\begin{array}{l}34.42 \\
28.36\end{array}$ & $\begin{array}{l}32.12 \\
26.04\end{array}$ & $\begin{array}{l}31.92^{7} \\
28.20\end{array}$ \\
\hline
\end{tabular}

Source: NAB Annual Reports 2001-2004 and KPMG Financial Institution Performance Surveys, Years 2001-2005 (Company figures from $\mathrm{NAB}$, other data from KPMG indicated by*)

Return on Assets (ROA) a measure of efficiency, indicates management's ability to use financial and real resources to generate net revenue. The return on assets for an ADI is a function of both its cost management, reflected by its net profit margin and its revenue management captured by its asset utilisation ratio. The net margin calculated by operating income after tax divided by interest income measures the profit margin, that is, what is left out of one dollar's revenue after all costs have been taken out. NAB's data demonstrates some variability in its net profit margin particularly reflecting the impact of the losses in 2004 and ongoing cost efficiency issues in 2005.

\footnotetext{
5 This sector is made up of the five largest banks that include NAB, Commonwealth Bank of Australia, Australia and New Zealand Bank, Westpac and St. George Bank.

${ }^{6}$ Notes to table 3: Interest Margin (net interest income/ earning assets), Net (Profit) Margin (operating profit after tax/ interest income), Asset Utilisation (interest income/ assets), Return on Assets (operating profit after tax/assets), Leverage (equity) Multiplier (total assets/shareholder equity), Return on Equity (operating profits after tax/ shareholder equity), Operating Expenses/ Average Total Assets (operating expenses are total expenses (before tax) less interest expenses, excluding BADD and goodwill amortisation expense), Cost to Income Ratio (costs include total expenses, Capital Adequacy Ratio (risk-weighted capital calculated according to regulators requirements)

7 NAB share prices for first half 2005 are recorded with the Low of AUD28.20 at Jan 2005, and the High of AUD31.92 as at May 30, 2005 (The Australian Financial Review, (2005) "Market Wrap", p.37
} 
The asset utilisation ratio or yield reflects how effectively management has invested in earning assets by calculating the overall yields earned on the assets. NAB's asset utilization ratio fell from 5.15\% in 2001 to a low of $4.06 \%$ in 2003 with recovery occurring in 2004, whilst its financial leverage ratio remained high at above $14 \%$ over the four year period. Typically ADIs have relatively low ROAs, but because of their high financial leverage ratio they are able to generate reasonably acceptable ROEs, which makes them competitive, as an investment option, with nonbank firms.

It is not sufficient to use only the DuPont model for evaluating ADI performance. The cost efficiency ratios, such as Operating Expenses/Average Total Assets and the Cost to Income ratio are the most complete measures of overhead use. The cost to income ratio poses operating costs or overhead as the input to banking activities (the numerator) and operating revenue ie. net interest income plus non-interest income, as the output (the denominator) being produced by overhead. The smaller the values of these cost efficiency ratios the greater the efficiency (Hogan et al, 2004). The efficiency ratios for NAB are of some concern as the cost to income ratio for all other major banks has improved steadily over the past three years with the sector average at 49.2\% (KPMG 2004). NAB might be the biggest bank, but by no means is it the best, lagging the other four majors in most key financial measurements. NAB's cost to income ratio jumped to 57.4\% in the March 2004 half-year report, up from 50.8\% at the same time in 2003. The ratio is sharply higher than any of its four main rivals, ANZ reported a cost to income ratio of 52.7\%, Westpac's fell to $48 \%$, whilst St George bank boasts the lowest cost to income ratio of just 45\% (Johnston, 2005).

Good corporate governance practices are increasingly important in determining the cost of capital in a global capital market. Australian companies must be equipped to compete globally and to maintain and promote investor confidence both in Australia and overseas. McKinsey and Company (2002) discovered in their USA Global Investor Opinion Survey on Corporate Governance that good corporate governance affected investor confidence:

- $\quad 63 \%$ investors would avoid companies with poor corporate governance

- $\quad 57 \%$ would change their holdings

- $\quad 31 \%$ would avoid investing in countries known for poor governance practice and regulation

- $\quad 28 \%$ would change their holdings in some countries if their governance practice varied

- $\quad 73-78 \%$ would pay a premium for a well governed company

This suggests that investors are willing to pay a higher price and to change their shareholdings for companies with good corporate governance. This was clearly shown with the sudden $5.5 \%$ fall in the NAB share price on the NYSE following the announcement of the HomeSide loan debacle in July 2001 (Collections World, 2001). The impact was more dramatic and significant on the ASX with NAB's ordinary share price falling by $33 \%$ from a high of AUD35.13 in July to a low of AUD23.80 by September 2001. As the recent foreign currency scandals came to light NAB share price again dramatically fell 19\% from a high of AUD32.12 in January 2004 to AUD26.04 by September 2004, with partial recovery in the share price occurring slowly over many months. A year later and despite the revamping of the board, the share price of NAB is still hovering around AUD30.00 and NAB's lead position in the major bank share prices was given over to CBA shares in mid-2004, a position CBA continues to retain with its shares currently trading significantly higher than NAB's at AUD37.38 (Commsec, 2005).

\section{REGULATORY AND COMPLIANCE ISSUES}

What lessons can be learnt by other banks and regulators? Other Australian banks have watched as the largest Australian bank has undergone "public chastisement" in the period immediately following the foreign exchange debacle in January 2004. The regulatory response to NABs trading losses was scathing, indicating that its culture had impeded transparency and led to poor oversight and weak risk management (Gluyas, 2005). APRA implemented a series of remedial actions that required NAB to comply with a series of 81 actions, imposed on-site supervision until the actions were implemented, and raised NAB's internal target total capital adequacy ratio ${ }^{8}$ to $10 \%$, up from the Group's previous internal capital ratios of 9-9.5\%. NAB's approval to use an internal model to determine market risk capital was withdrawn and the currency option desk closed to corporate business until all areas of concerns in the

\footnotetext{
${ }^{8}$ Australian Banks adhere to the international capital adequacy requirement of a minimum $8 \%$ risk-weighted capital.
} 
APRA Report were addressed. Risk management strategies that had to be implemented prior to NAB's foreign currency option desk re-opening included increased monitoring of all market risk limits with mandatory "hard" limits and trigger or "soft limits" which included a defined response. Over a year later, in May 2005, the foreign currency option desk reopened after undergoing the significant restructuring as required by the APRA/PwC recommendations. NAB has submitted 71 of the 81 required remedial measures (with 31 items completed by March 2005), the bank must still comply with the regulator's risk model and is required to hold the higher specified capital until APRA is satisfied that the weaknesses in the Report have been fully rectified (NAB 2004 Annual Report and APRA 2004). The use of the so-called standard model (regulator's model) for calculating NAB's regulatory capital needs for market risk has required the bank to carry about AUD450 million in extra regulatory capital than if allowed to use the more sophisticated internal models. Part of NAB's 8\% increases in its cost to income ratio over 2004-2005 has been attributed to the added cost of compliance with APRA requirements (Oldfield, 2005).

This significant NAB corporate governance failure resulted in a review by APRA and Price Waterhouse Coopers (PwC). The forensic work done by the accounting firm helped close off gaps in NAB's trading system and rule off losses relatively quickly. Concerns regarding the independence of this $\mathrm{PwC}$ report and the APRA report should be raised as PwC, who were the "external experts" asked by the NAB to audit the scandal, already had a close and extensive relationship with the NAB board. The PwC report was commissioned by Cathy Walter and Frank Cicutto, both resigned from the board before the report was tabled. Charles Allen the chairman of the board also resigned before the report was tabled, compounding the disaster. Elevating this report to the status of an independent report (which is what happened) leaves it open to criticism, and particularly when Walter began rasing concerns about it with her fellow directors. The APRA report can also be considered less than ideal as the regulator established a small team who then utilised the factual information provided by the PwC investigative committee appointed by NAB board directors and the CEO (Maiden, 2004).

There is no single model of corporate governance and the ASX Corporate Governance Council provides ten core principles with implementation guidance in the form of best practice recommendations. There is significant flexibility as the Council recognizes that there is no one size fits all in relation to corporate governance and the extreme diversity in company type and size. Companies can assess and make their own decisions regarding their governance structures within the recommendations and suggestions from the Council's guidelines. But it is subject to disclosure on an "if not, why not?" basis, which means that a company need not implement or adopt the recommendations, but there is the requirement to explain why not (ASX 2003).

Under the ASX Company Listing Rules, 2004 was the first year that listed trusts and companies were required to provide disclosure against the ASX Corporate Governance Council's Principle's of Good Corporate Governance and Best Practice Recommendations in their annual report. The burden of meeting these formal requirements should not be underestimated as it requires significantly more reporting and the risk structures and internal controls must at least be alluded to, be in the process of implementing or have been implemented. The Council's recommendations are not mandatory and cannot, in themselves, prevent corporate failure or mistakes in corporate decision-making, but they can provide a reference point for enhanced structures to minimize problems and optimize performance and accountability (ASX, 2003). The extent of the reporting burden can be seen in the significant increase in the attention committed to corporate governance issues in the NAB annual reports over the past four years. Corporate governance issues in NAB annual reports have increased more than threefold from three pages in 2001 to ten pages in the 2004 annual report.

Whilst NAB has complied with the letter of the law in terms of compliance with the ASX Principle's of Good Corporate Governance, it seems that the spirit was missing. The risk committee was formed in August 2003 but there were no meetings held during 2003, interestingly enough this was at the very time that risk systems were being breached at NAB and was soon to blow up into the foreign currency scandal (NAB Annual Report 2003). It was further admitted by John Stewart, the new CEO, in an interview with Michael Pascoe (2004) that there were no nonexecutive members on the risk committee with any banking experience. The chairman and then CEO were part of this Committee and with direct lines of accountability and responsibility; it was only going to be a matter of time before they both would need to step aside from their positions. Mr Graham Kraehe, chairman of this risk committee, took over the role of Board Chairman after Mr Charles Allen stepped down following the breaking of the news in the 
media. It seemed inappropriate that the board member presiding over the risk committee, which had failed in its basic requirement to manage risk practices, should take over the chairman position. The Board lurched about uncertainly for 2-3 months as claim and counter-claim and motions of no-confidence were lodged at Board Members. The Board geared up for a general meeting of shareholders to resolve the issues of board membership in May 2004 but the meeting failed to go ahead as finally deals were struck for some members of the board to step down immediately with others resigning according to a phased-in time-table, avoiding, by the narrowest of margins, the public blood-letting. These issues relating to the risk committee were addressed during 2004 when all new members, having appropriate experience, were appointed to the mandatory risk committee changing its public and private face substantially. The committee met 18 times during 2004, in direct contrast to the previous year when no meetings were held (NAB 2004 Annual Report).

In regards to regulation in an international context the "principle versus the detailed rules" debate has been closely followed with the USA and Australia adopting a method in 2003, which provides flexibility and not the "onesize-fits-all" approach that occurs with regulation. Policy implications from Hart's (1995) analysis support this view as he finds that the use for statutory rules is weak; rather the Cadbury (UK) approach of trying to educate companies to make changes in corporate governance is probably superior. Rules are no substitute for market mechanisms, such as the takeover mechanism, that exists and ensures that companies are well managed.

The debate of rules versus principles continues, but the ASX has come down in favour of mainly principles with some mandatory requirements. Regulation of auditors is not sufficient to address problems of auditor independence. It needs to be complemented by the strengthening of the role of the audit committee. The GCAA (2003) is not as strict as the SEC and does not advocate a total ban on provision of all non-audit services by auditors of the company, as there are good business reasons of efficiency and synergy to purchase non-audit services, such as tax planning, tax advice and tax compliance, subject to audit committee pre-approval. An exception to the disclosure requirement of "if not, why not?" applies regarding audit committees for companies comprising the Australian S\&P/ASX All Ordinaries Index. The ASX Listing Rules mandate the establishment of audit committees by those companies and require that the composition, operation and responsibility of the audit committee comply with the Council's best practice recommendations. It was expected that these companies would have an internal audit committee formed by the first day of their 2004 financial year, but the ASX have allowed transitional arrangements until June 2005 (ASX, 2005).

\section{Further Regulatory Reform}

Risk management may need further legislation, such as the new prudential standards on business continuity management (BCM) for authorised deposit-taking institutions (ADIs) and general insurers issued by APRA in May 2005. These new prudential standards aim to ensure that ADIs and general insurers implement a "whole of business" approach to BCM appropriate to the nature and scale of their individual operations. It will require the Board of Directors and senior management of an ADI or general insurer to consider business continuity risks and controls as part of the company's overall risk management framework provided to APRA on an annual basis. Further resources will be required in the risk assessment area and prudential supervisors may well require ADIs to hold more capital and increase the level of public disclosure in line with the ASX's principles of good governance.

A number of issues arise in regards to auditor independence. Firstly, auditor capture may occur, where the auditor has too close an identification with the firm and its management, even where this may be contrary to shareholder interests. Secondly, the audit firm may be concerned about losing major clients to be objective in their reporting, and thirdly, the effective control of auditor appointment and remuneration may be controlled by the executive directors. The enforcement of independence of internal and external auditors already occurs in the US, but is unlikely to become a requirement in the UK or Australia, as their Corporate Governance Councils hold strong views on enhancing the role of the audit committee via the 'comply and explain' approach over the legislative approach. (CGAA, 2003). The question that needs to be asked is whether it is possible to have independent auditors and other financial services from the big four accounting firms. To avoid the possibility of auditor capture, mandatory rotation of auditors is suggested, but the US experience suggests problems with mandatory rotation of auditors. Laxness may occur as the auditing firm knows it is not keeping the client; there is reduced need to prove performance as it is just a 
'matter of waiting your turn' until your rotation, along with declining numbers of the large audit houses and industry rationalisation over the years it would be difficult to implement successfully. Although this problem could be reduced if compulsory tendering was implemented with the incumbent audit firm disallowed from re-tendering.

There would seem to be a need for increased and more effective monitoring by the regulator and the question should be asked whether APRA played a proactive enough role. There was considerable laxness in APRA's oversight of NAB with failure to act promptly to warning signals (NAB 2004 Annual Report). APRA's reliance on the PwC investigation into the foreign currency losses also seems inappropriate. To avoid potential conflicts of interest the regulator needs to have sufficient resources to run its own independent audit committee/ investigative committee rather than relying on one of the big four accounting firms to undertake the factual part of the review, as happened in the NAB review. Mandatory 'arm's length' investigation and more powers to be granted by legislation to the regulatory body may mitigate some of these concerns.

\section{CONCLUSION}

A review of the NAB's recent corporate governance failures suggest that problems existed in the culture, the controls and the management of risk in this organisation for some years. Cornell (2005) states that Stewart (CEO) is not just unwinding the past five years of mismanagement under Cicutto, but he is also unwinding the disasters from the preceding CEO. The lack of accountability by the management and the Board seems to have stemmed from at least the HomeSide incident if not before. Maiden's (2004) view is that seeds were sown in 2001 when no director or board member took responsibility or the 'fall' for the AUD4.1 billion losses that occurred. Management and the Board provided shareholders with only a summary of an internal report into how the money was lost. The 2004 foreign currency losses pale into insignificance beside the HomeSide losses, and again the Board escaped reasonably lightly from the inquiry with the PwC and APRA reports focusing on management mistakes and structural flaws in the risk oversight system. The disastrous events that unfolded concerning the Board came more from the failure to defuse disagreement between Board members before it became a public war.

The DuPont analysis allowed a comparison of NAB's performance in terms of profitability and cost efficiency. The net (profit) margin and ROE showed distinct variance in the years following both the Homeside and foreign currency losses and the cost to income ratio, a measure of efficiency, slipped to $57.4 \%$ from $50.8 \%$ a year earlier. The significance of this increase in costs is in the comparison with NAB's peers where the average for the sector was 49.2\% (KPMG 2004). The share price on the ASX experienced significant falls in the year of each of the events, and a year later is trading at more than AUD7.00 below the CBA, its strongest competitor. The view of market commentators and John Stewart, CEO, is that the bank has now hit 'the bottom' and after stabilising, can begin recovery with plans to cut 4,200 jobs as a means of controlling the cost-income ratio (Cornell, 2005).

The events that occurred provided the stimulus for significant changes to the legislation and the principles concerning corporate governance but with all rules and regulations it is necessary to balance the public interest of imposing rules and providing strong guidelines. The current environment for corporate governance in many countries can be described as co-regulatory, where there is a mix of principles and mandatory requirements. There are strong incentives to continue this stance worldwide as increasing globalization of capital markets sees a growing recognition and desire to achieve uniformity and harmonization in areas of auditing and good principles of corporate governance.

\section{REFERENCE LIST}

1. Australian Prudential Regulatory Authority (2002), APRA increases its focus on Corporate Governance, Media Releases, http://www/apra.gov.au/media-releases/02 41.cfm, accessed 21/5/05.

2. Australian Prudential Regulatory Authority (2004), Report into Irregular Currency Options Trading at the National Australia Bank, March.

3. Australian Prudential Regulatory Authority (2005), Discussion Paper: Governance for APRA- regulated institutions, http://www.apra.gov.au/RePEc/RePEcDocs/Archive/discussion papers/dp0019.pdf, accessed 20/5/05. 
4. Australian Prudential Regulatory Authority, (2005) APRA determines new prudential standards on business continuity management Media Release No. 05.22, http://www.apra.gov.au/media-releases/05_22.cfm.

5. (ASX) Australian Stock Exchange Corporate Governance Council, (2003) Principles of Good Corporate Governance and Best Practice Recommendations, http://www.shareholder.com/shared/dynamicdoc/ ASX/364/ ASXRecommendations.pdf, accessed 30/03/05.

6. ASX (2005) Analysis of Corporate Governance Practice Disclosure, May $16^{\text {th }} 2005$, pdf. http://www.shareholder.com/shared/dynamicdoc/ASX/364/ASXRecommendations.pdf, accessed 30/03/05.

7. Berle, A.A. and Means, G.C. (1932) The Modern Corporation and Private Property, Macmillan, New York.

8. Chiang, H. (2005) An Empirical Study of Corporate Governance and Corporate Performance, The Journal of American Academy of Business, pp. 95-101.

9. Clarke, T. (2004) Cycles of Crisis and Regulation: the enduring agency and stewardship problems of corporate governance. Corporate Governance, 12 (2), pp.153-161.

10. Collections World (2001) HomeSide Takes a Hit, July 16, http://www.creditcollectionsworld.com/ news/071601 4.htm, accessed 04/05/05

11. Coase, R.H. (1937) The Nature of the Firm, Economica, (New Series), 4, pp. 386-405.

12. Collett, P. and Hrasky, S .(2005) Voluntary Disclosure of Corporate Governance Practices by listed Australian Companies, Corporate Governance, 13 (2), pp. 188-196.

13. Commsec (2005) NAB share price, http://commsec.com.au/ClientAccess/ NewsResearch?CMS TabGraphs.asp, accessed 9/05/05.

14. (CGAA) Coordinating Group on Auditing and Accounting Issues in the UK (2002) Online document at URL www.nabarro.com/uploads/files/266.pdf, accessed 23/5/05.

15. Daily, C.M. and Dalton, D.R. (1999) What's wrong with having friends on the board?, Across the Board, 36 (3), pp. 28-32.

16. Doucouliagos, H. and Hoque, M.Z., (2005) Corporate Governance and Australian Bank Stock Prices, Unpublished Paper, Deakin University, Melbourne.

17. Earl, M. J. (1983) Perpsectives on Management, Oxford University Press, Oxford.

18. European Corporate Governance Forum (2004) http://europa.eu.int/rapid/ pressReleasesAction.do?reference=IP/04/1241\&format=HTML\&aged=1\&language=EN\&guiLanguage=en.

19. Farrar, J.(1999) A Brief Thematic History of Corporate Governance Bond Law Review, 11(2), pp .259-279.

20. Gardner, M. J., Mills, D. L., and Cooperman, E. S., (2004) Managing Financial Institutions: An Asset/Liability Approach, ( ${ }^{\text {th }}$ Edition), The Dryden Press, Harcourt College Publishers, Orlando, FL.

21. Gay, G. and Simnet, R., (2000) Auditing \& Assurance Services in Australia, McGraw Hill, Sydney.

22. Gluyas, R., (2005) NAB forex desk is back with anti-rogue remedy, The Australian, 19.04/05, http://theaustralian.news.com.au/common/story_page/0.5744, accessed 27/04/05.

23. Hart, O., (1995) Corporate Governance: Some Theory and Implications, The Economic Journal, 105, May, pp. 678-689.

24. Heracleous, L. (2001), What is the impact of Corporate Governance on Organisational Performance? Corporate Governance, 9 (3).

25. Higgs, D., ( 2003) Review of the Role and Effectiveness of Non- executive Directors Online document at URL http://www.dti.gov.uk/cld/non exec review/pdfs/higgsreport.pdf.

26. Hogan, W., Avram, K., Degabriele, R., Ralston, D., Skully, Hempel, G., Simsonson, D., and Sathye, M., Management of Financial Institutions, (2 $2^{\text {nd }}$ edition), John Wiley \& Sons, Australia.

27. Hoy, G., (2002): Concerns around NAB despite top bank rating, Inside Business, 27/10/2002, http://www.abc.net.au/insidebusiness/content/2002/s711978.htm accessed 26/04/05.

28. Johnston, E., (2005) It's Australia's biggest but by no means best, The Australian Financial Review, May 12, p. 25.

29. Karathanassis, G. and Philippas. N., (1998) Estimation of Bank Stock Price Parameters and the Variance Components Model, Applied Economics, 20, pp.497-507.

30. Korac-Kakabadse, N, Kakabadse, A. K., and Kouzmin, A. (2001) Board Governance and Company Performance: any correlations? Corporate Governance 1(1), pp. 24-30.

31. Kiel, G. C. and Nicholson, G. J. (2003). Board Composition and Corporate Performance: how the Australian experience informs contrasting theories of corporate governance, Corporate Governance 11 (3), pp. 189-205.

32. Maiden, M., (2004) Out of the frying pan into the fire, The Age, 3 May 2004. 
33. McKinsey \& Company (2002) Global Investor Opinion Survey on corporate Governance, http://www.mckinsey.com/governance.

34. Mellish, M. (2001) Bank out of its depth in the US, Australian Financial Review, 5 Sept, p.1.

35. Morck, R. and Steier, L. (2004) The Global History of Corporate Governance: An Introduction, NBER Working Paper No.W11062, National Bureau of Economic Research, Inc. http://www.nber.org/books/corpowner03/introduction11-9-04_FINAL.pdf accessed 27/05/05.

36. Nadler, D. A. and Tushman, M.L., (1980) A Model for Diagnosing Organizational Behaviour, Organizational Dynamics, 9, pp.35-51.

37. National Australia Bank (2004) The Year The Facts The Future: The Concise Annual Report 2004 http://www.nabgroup.com/vgnmedia/downld/Concise NAB04.pdf accessed on 27/05/05.

38. Nicholson, G. J. and Kiel, G. C. (2004) A Framework for Diagnosing Board Effectiveness, Corporate Governance, 12 (4), pp. 442-460.

39. Oldfield, S. and Cornell, A., (2004) NAB caught in auditing crackdown, The Australian Financial Review, Feb $27^{\text {th }}$, p. 1,73 .

40. Parker, S., Peters, G. F., and Turetsky, H.F. (2002) Corporate Governance and Corporate Failure: a survival analysis, Corporate Governance, 2 (2), pp. 4-12.

41. Pascoe, M. 2004. Sunday Sunrise. http://seven.com.au/sundaysunrise/finance/18471 accessed 14/04/05.

42. $\quad$ Sengupta, P. (1998) Corporate Disclosure Quality and the Cost of Debt, The Accounting Review, 73, pp. 459474.

43. Woodward, S., Bird, H., and Sievers, S. (2001) Corporations Law: in Principle, (5 ${ }^{\text {th }}$ Edition). Law Book Co, Sydney. 


\section{NOTES}

